\title{
AN ASSESSMENT OF FRANCOIS BERNIER'S TRAVEL ACCOUNT: A FRENCH COMMERCIAL INFORMER OR A CRITIC OF THE FRENCH STATE?
}

\section{Dr. Sakul Kundra*}

\begin{abstract}
French commercial and, later, political expansion in South Asia from 1600 to 1800 has attracted the attention of many historians. French travellers played a significant part in exploring overseas markets and establishing commercial links between Europe and South Asia. However, there has been a lack of historical research, on assessment of commercial information regarding India and its converse impact on the French state, provided by Francois Bernier in his travellers accounts. Therefore this article made an attempt to make an assessment of Francois Bernier's Travel account in relation to its commercial relevance. An attempt shall be made to present a true picture of Bernier's contribution in analyzing Indian commercial prospects and his hidden warning to Louis XIV against politicizing his ambitious goals to expand his political control over the need for improvement of French commercial structures
\end{abstract}

Keywords: French traveler's accounts, Commercial expansion, Comparing French and Indian commercial interlinks and Travelers interpretation.

*Assistant Professor, Lakshmibai College, Delhi Univers, India 
French commercial and, later, political expansion in South Asia from 1600 to 1800 has attracted the attention of many historians. French travellers played a significant part in exploring overseas markets and establishing commercial links between Europe and South Asia. However, there has been a lack of historical research, on assessment of commercial information regarding India and its converse impact on the French state, provided by Francois Bernier in his travellers accounts. Therefore this article made an attempt to make an assessment of Francois Bernier's Travel account in relation to its commercial relevance.

This article highlights two basic arguments simultaneously related to the information provided by Bernier's accounts. Firstly, Bernier's accounts had conveyed a significant amount of commercially significant information to French state. His contribution stands foremost in familiarizing the French with the available commercial opportunities in India and mercantilist mechanism of India, notwithstanding the French failure to extract commercial benefits from India, as compared to the other European powers. He gave substantial guidelines to the French commercial overseas explorers for dealing adroitly with the Indian authorities at central and provincial level. He facilitated the Frenchmen to scrutinize the sites for their factories and created awareness among the French embassies about the Indian customs and practices. His travel records discussed important issues that were mandatory for the French explorers to know in order to achieve commercial success in India. The information regarding Indian geography, metallic content of the currency, economic conditions of various sections existing in Indian society, Indian imports and exports, Indian revenues statistics, diplomatic tactics and measures adopted by the French rival European companies to extract benefits from the Indian trade and lots more. His travel records present him like a 'commercial informer for French State', who explored the Indian economic structure and suggested essential measures to Louis XIV and Colbert for establishing French trade with India.

Secondly, Bernier constantly compared the commercial structure of India with that of France. He gave a veiled message accusing the French Monarchy for its weak commercial policies. As Louis XIV's priorities to establish political hold over commercial expansion hampered the financial reforms taken by Colbert. This finally led to the decline of French trade in Indian Oceans. Direct accusation against French Monarch was not accepted under Louis XIV's absolute rule. Therefore, Bernier took India as an example to show the negative consequences of despotic policies of the Mughals in regards to their policies over their economic structure. It gave a suggestion to Louis XIV for checking his absolutist policies otherwise it may have to face the negative consequences as happening in India.

After taking this overall picture into consideration, an attempt shall be made to present a true picture of Bernier's contribution in analyzing Indian commercial prospects and his hidden warning to Louis XIV against 
politicizing his ambitious goals to expand his political control over the need for improvement of French commercial structures.

\section{French Travellers' in Mid-17th Century}

The French travellers throw a valuable light on the trade and economy of India in mid $17^{\text {th }}$ century by leaving valuable accounts of their observations and experiences in the form of memoirs, diaries, journals, travelogues, personal letters, communications addressed to their friends and relatives in Europe, and official papers and reports of their missions. Some French travellers gave vivid description regarding the economy of India and provided invaluable information on subjects like Indian coinage, weights and measures, mineral wealth of Mughal India, price of mineral articles, popular trade routes principle Indian and foreign ports in Indian seas, important trading centers, customs and tariffs of period. On the whole, these travellers drew an almost complete picture of the economy of the period. ${ }^{1}$ Firstly, Jean Baptiste Tavernier, ${ }^{2}$ a merchant by profession, who traveled to India six times, provided considerable authoritative record of the Mughal economy. Tavernier's description of the trade and economy of Mughal Empire forms a vital source of economic history of that period and his treatment of the subjects was logical and almost free from inherent biases and prejudices. Secondly, Jean de Thevenot ${ }^{3}$ and Jean Chardin ${ }^{4}$ also left behind valuable accounts of India in the $17^{\text {th }}$ century. Thirdly, records of two French travellers, Francois Martin ${ }^{5}$ and Abbe Carre ${ }^{6}$, who were associated with the French East India Company, gave important insights about the commercial avenues and opportunities available in India. These travellers also tried to sketch a picture of the relationship shared among the Indian merchants in pre-colonial India, and assumed that the Mughal state was, by and large, oppressive, adopted antithetical attitude towards commerce, made large extortions, imposed arbitrary cases on merchants and mercantile property and gave concessions to the Europeans in terms of preferential custom rates.

In spite of these miscalculations in understanding the relations of the Indian merchants and the Mughal state by French travelers, Francois Bernier's travel accounts provided a more analytical and comparative account of the Indian and French commercial structures. His account had fewer shortcomings as compared to rest of the French travellers in mid- $17^{\text {th }}$ century, and his uniqueness was his constant comparison of the commercial potential of French and Indian state. Bernier tried to satisfy the French urge of commercial expansion by providing valuable accounts like describing the customs and practices prevailing in India; demonstrating graphic picture of Indian revenues and explaining reasons for accumulation of gold and silver metals in India, and lastly, he indicated the means, which should be adopted by the French state to be a successful commercial power in India after defeating their European rivals. 


\section{Impact of Louis XIV's French Commercial Expansion in Indian Subcontinent}

The rise of centralized states in the $15^{\text {th }}$ century Europe with strong monarchs gave encouragement to geographical discoveries and explorations, overseas expansion and colonization. There was political instability under the Bourbon dynasty during Louis XIII, and Louis XIV, the new King had assumed personal rule in 1661 and was determined to reduce the nobility and all other sources of potential opposition to obedience under the absolutist crown. Louis XIV, in the quest for territorial gains and his dynastic ambitious ignored the potential of Colbert's Asian campaign and retarded French ambitions in the Indian Ocean trade and reduced France to an inferior position in the capitalist world economy. Colbert's effort to achieve national economic stability and self-sufficiency ${ }^{7}$ could not withstand the insatiable demands of Louis XIV's increasingly expensive war. ${ }^{8}$

The French mercantile activities were controlled by the government to such an extent that they diminished the drive, skill and initiative of the company. The French East India Company was compelled by the state direction to govern its colonies in accordance with the laws of Paris. The link between the merchants and the government was the key for commercial progress, as the merchants depended on their governments to provide a navy to protect and defend their overseas investments, and governments depended equally on entrepreneurship, not only to generate money to build ships, but also to sustain trade upon which national power had come to rely on heavily. ${ }^{9}$ Thus, the French East India Company was not based on a solid support from the rising capitalist class, but it was dependent on the controller-general's power and his ability to arrange investment and support from a Crown and aristocracy, despite his best efforts, continued to view the campaign as merely as an extension of dynastic struggles in Europe. ${ }^{10}$ Internal fighting among the Directors of French East India Company immensely harmed the commercial interests of the company in India; these were, Caron and Marcara Avacinz. ${ }^{11}$ Thus it can be summed up that the political formulation under Louis XIV was one of the prime causes for the failure of French in the Indian Ocean.

\section{Francois Bernier's Association with Jean-Baptiste Colbert}

Francois Bernier wrote his account 'Travel in the Mogul Empire AD 1656$1668^{\prime}$ in French language and probably for the French state, the commercial merchant class and French masses. Notwithstanding this, the account was not altogether based according to the whims and fancies of the French East India Company. Albeit, he was in constant touch with the finance minister of Louis XIV, named Jean-Baptiste Colbert (1619-1683). Bernier wrote to him in a sycophantic language to please him. He said "It was in Hindoustan, My 
Lord, whither your fame extends and from which country I am lately returned after an absence of twelve years, that I first became acquainted with the happiness of France and with the share which you have had in promoting it, by your unwearied attention and brilliant abilities." 12 Tavernier after his arrival in France, had an interview with Louis XIV and he sold the king a large number of diamonds and other precious stones, and, on February 1669, in consideration of his eminent services to France, he was granted letters which conferred upon him a title of nobility. ${ }^{13}$ Bernier in his travel accounts, addressed one letter directly to Colbert, explaining the possibility of trade between France and India, "concerning the extent of Hindoustan, the currency towards, and final absorption of gold and silver in that country; its resources, armies, the administration of justice and the principal cause for the decline of the states of Asia." "In 1668, Francois Bernier, was on his way back to Europe after a stay for eight years at the court of the Great Mughal. At Surat, he met M.Carron, who had been given the responsibility to lay the foundation of trade between France and India on behalf of the French East India Company (La Compagnie des indes Orientales). It was on Carron's request that Bernier wrote the memoir. ${ }^{15}$ Bernier probably wrote to Colbert because he wanted employment and to get his travel records published. When he returned to France, he tried to approach Colbert via Chapelain with a view to gain an audience with the King. Finally, Bernier succeeded in getting a license with the favour of the King, dated on $25^{\text {th }}$ April 1670, at Paris. ${ }^{16}$ Therefore, Bernier was writing for the French readers, and he needed the help of Louis XIV for getting his record published. So, a direct accusation of the French monarchy's weak commercial policies was not possible. Bernier dedicated "Travels in the Mogul Empire 1656-1668" to King Louis XIV, in 1670, Paris edition. ${ }^{17}$ Bernier conveyed directly to Colbert the avenues available for the French Company in the Indian seas; demonstrating the immense the wealth and riches of the Mughal empire and depicted the causes for the weakness of French commercial policies.

\section{Grandeur and Glorification of French and Indian Emperors}

The wealth and grandeur of the Mughal Empire is elaborately described by Bernier. Bernier compared Shah Jahan amassing huge wealth without engaging in warfare in comparison to Louis XIV's ambitious military expansions creating financial bankruptcy in France. He said, "ChahJehan,(Shahjahan) who was a great economist and reigned for more than forty years without being involved in any great war." 18 Bernier's description of Mughal wealth was exaggerated. According to M.Athar Ali, there was no increase in the income of the Mughal state after 1605 A.D. It was due to this reason that Shah Jahan introduced monthly scale in the mansabdari system.

The memorandum of Bernier provided statistical data of the revenues received by the Great Mughals. He estimated that the combined revenue from the Mughal subahs, parganas and sarkars was twenty two Kouroures 
$(22,59,35,500 \text { exact })^{19}$ and pointed out huge discrepancies between the estimated and collected Mughal revenue. ${ }^{20}$ He probably correlated this to the problem of discrepancy between the amount of tax collected and actually deposited to the royal treasury in France, as the major portion was absorbed by the French tax-farmers and tax-collectors. No uniform system of taxation operated in France; each province was taxed separately, with the varying incidence of both direct and indirect taxation, levied by different methods and with varying degrees of favouritism or hardships. ${ }^{21}$

Mughal king's appearance was describe by Bernier, "King appeared seated upon his throne, at the end of the great hall, in the most magnificent attire, his vest was of white and delicately followed satin, with silk and gold embroidery of the finest texture." ${ }^{22}$ In describing the Mughal throne, he wrote "the throne was supported by six massy feet, said to be of solid gold, sprinkled over with rubies, emeralds and diamonds and the throne valued at four kourours of roupies." ${ }^{23}$ These references to the Mughal king's appearance and throne probably echoed Bernier's concern about the ongoing trend of the glorification of French monarchy under Louis XIV's rule since his coronation in 1661. This exaltation of royalty became conspicuous in 1682 with the building of Versailles palace by Louis XIV. ${ }^{24}$ The palace was designed to appear to his subjects as a temple dedicated to the worship of demigod and this elevated the King above the rest of mankind. ${ }^{25}$ Bernier certainly wanted to draw the attention of the French state towards the huge financial expenditure and monetary losses incurred by the French economy in Louis XIV's ostentatious celebration of monarchy. Bernier also described the way through which Mughal emperor collected huge amounts of wealth. He said, "all these precious stones, and valuable articles, are the spoils of ancient princes, patans and rajas, collected during a long course of years, and increasing regularly under every reign, by presents which the omrahs are compelled to make on certain annual festivals." ${ }^{, 6}$ This enormous amount of precious material belonged to the King. He said, "the whole of this treasure is considered the property of the crown, which it is criminal to touch, upon the security of which the King, in a time of pressing necessity." 27 This forcible collection of treasure created displeasure and dissatisfaction among some Indian nobles. This situation was comparable with the French nobles whose financial privileges were taken away after the enthronement of Louis XIV in 1661.

The real state of the great Mughal was described by Bernier. He gave an indirect hint to the French state on the way of governance. He said, "although the Great Mogol is in receipt of immense revenue, his expenditure being much in the same proportion, he cannot possess the vast surplus of wealth that the most people seem to imagine... I should call that King effectively rich who, without oppressing or impoverishing his people, possessed revenues sufficient to support the expenses of a numerous and magnificent court, to erect grand and useful edifices, to indulge a liberal and kind disposition, to maintain a military force for the defense of his 
dominions and besides all this, to reserve an accumulating fund that would provide against any unforeseen rupture with his neighbors, although it should prove of some years durations." 28 These words of Bernier about the Indian structure and the state of Great Mughals seen to give an indirect advice to the absolute French monarch, Louis XIV, as to how an effective monarch should govern without oppressing the people, and one should always reserve resources for unforeseen emergencies, military operations and political expansions. Colbert's efforts to achieve national economic stability and self-sufficiency could not withstand the insatiable demands of Louis XIV's increasingly expensive wars. Nor did his overseas trading companies ever achieve the stature of those of the England and the Holland. Therefore, Bernier was using the Indian structures as instances to indicate the systemic loopholes and defects prevailing under Louis XIV's policies.

\section{Question of Precious Metal in India}

Numerous stories about the fabulous riches of the east were recounted by Bernier. He explained the position of Indian metallic balance. He stated: "gold and silver come from every quarter of the globe to Hinduostan, to be swallowed up and in large measure to remain permanently in India. From Europe and America, gold goes to Turkey in payment for goods imported from it; from Turkey by further trade with Persia and Yemen, it passes to Hindustan in exchange for the three celebrated ports of trade, Moka on the Red Sea, Bassora on the Persian Gulf and Gomeron near Ormuz. On the South-East Asian side, Indian vessels, whether they belonged to Indians or the Dutch, English or the Portuguese, carried merchandise from Hindoustan to Pegu, Tenasserim, Siam, Ceylon or Acheen from which countries it received a quantity of precious materials. Moreover a part of the gold and silver which Dutch drew from Japan also finds its way to Hindoustan. Although Hindoustan imported goods from all over the world. She obtained copper, cloves and nutmegs from the Moluccas and Ceylon, broad cloths from France, lead from England more than 25,000 horses from Usbec, Arabic and Persia; musk and porcelain from China; pearls from El Bahrein and Ceylon; rhinoceros horns and slaves from Ethiopia and immense quantity of dry fruits and fresh fruits from Samarkand, Bali, Bokhara and Persia." 29

Then, he explained, the real mechanism of the balance of trade, the importation of all these articles into Hindoustan does not however occasion the export of gold and silver because the merchants who bring them find it advantageous, to take back, in exchange the production of the country. ${ }^{30}$ Further, he stated, "supplying itself with articles of foreign growth or manufacture, does not therefore, prevent Hindoustan from absorbing a large portion of the gold and silver of the world, admitted through a variety of channels, while there are scarcely an opening for its returns." 31 Bernier also suggested that a country absorbing large amounts of precious metals like 
gold and silver should produce enough agricultural and manufactured goods to maintain their balance of trade. The availability of the precious metals was not enough to make a country rich in the long duration of time because gold and silver in them cannot provide more goods and services to the people, unless they are used for expansion of production. Otherwise that country is likely to become critically dependent on imports and its own potential will not be brought into use. Bernier stated that, "the precious metals must abound in Hindoustan, although the country is destitute of mines; and the Great Mogol, lord and master of the greater part, must necessarily be in the receipt of immense revenue, and possess incalculable wealth. ${ }^{32}$ Thus, Bernier tried to give an indirect lesson to Colbert to the effect that if France could produce manufactured goods as much in demand as in the land of Aurengzeb, then that could certainly ensure him of a positive flow of precious metals. France was facing the problem of shortage of money within its economy despite a great increase in coinage from 1640 to 1680 and large inflow of bullion from Spain. Much of this circulated media, especially in the 1660's and 1670's, comprised of silver and copper coins, and there were many complaints of good gold and silver leaving the country. ${ }^{33}$ The problem for French state was 'money'. The shortage of money could hinder the payment of taxes or lead to deflation and depression in the economic life. ${ }^{34}$ And with the increasing economic activity in Europe as a whole, the certainly growing need for precious metals grew. But due to increasing French military expenditure and grandeur the government was forced to increase taxation over masses. Thus, it became almost imperative for French state to take necessary measures to increase the manufactured goods and achieve a favourable balance of trade. Bernier gave an appropriate solution to the problem to the shortage of money in France.

\section{Indian Blockade of Precious Metals}

The paradox of the Indian economy that Mughal empire was an abyss for gold and silver was brought into forefront by Bernier as on the contrary, the "inhabitants have less appearance of a moneyed people than those of many other parts of the world." 35 Bernier explained that northern India received large quantities of gold and silver which were melted, re-melted and wasted, in the fabrication of women's bracelets and huge quantity ${ }^{36}$ was consumed in the manufacturing of embroideries. ${ }^{37}$ These precious metals thus got transformed into jewellery and other articles of personal adornment. This blocked the circulation and economic use of precious metals as an investible capital in the manufacturing processes in India. This was one of the reasons for the decline of Mughal empire given by Bernier to the European state.

Another reason was given by Bernier for the blockage of circulation of money. He said that the King was the proprietor of the land and, in lieu of regular cash payments, gave rights over the land to his nobles, provincial 
governors and military officers. The latter exercised these rights with absolute authority over the peasants, artisans and merchants and, in a cruel and oppressive manner. ${ }^{38}$ This tyranny deprived the common men of the fruits of their industry, which in turn obstructed the progress of agriculture and trade.

Attention of Bernier's reader was also drawn towards the superstitious beliefs prevailing in India and leading to the blockade of gold and silver. $\mathrm{He}$ stated, "when a person acquired wealth, the possessor, so far from living with increased comfort and assuming an air of independence, studies the means by which he may appear indigent... his gold and silver remain buried at a great depth in the ground; agreeable to the general practice among the peasantry, artisan and merchants, whether Mahometans or Gentiles ${ }^{39}$, but especially among the later, who possess almost exclusively the trade and wealth of a country, and who believe that the money concealed during life will prove beneficial to them after death." ${ }^{, 0}$ This information is also corroborated by Tavernier, who stated "there are some among them who are foolish enough to bury their treasures during their lifetime, as, for instance, nearly all the rich men of the kingdom of Assam, so that if they enter, after death, the body of any poor and miserable mendicant, they can have recourse to the money which they have buried in order to draw from it at necessity. This is the reason why so much gold and silver and many precious stones are buried in India, and an idolater must be poor indeed if he has not money buried in the earth." habit of secretly burying the precious metal and thus withdrawing them from circulation, is the principal cause of their apparent scarcity in Hindoustan., ${ }^{42}$

Bernier discusses the three aforesaid problems blocking the circulation and productive use of precious metals and in turn, commercial expansion in India in relation to the French problem of the lack of investment by the French bourgeoisie. As road of great wealth for French bourgeoisie lay not in trade and industry but rather in royal finances, the capital acquired in trade and industry was channeled into the purchase of rentes, of official posts and titles. Thus, there was a lack of private investment and private capital accumulation and the available surplus was almost entirely absorbed by expenditure on the maintenance of a large army and funding of continuous warfare. ${ }^{43}$ Therefore, France lagged behind the other maritime countries in commerce. In France, selling of official posts and titles had opened up an enormous avenue of uneconomical investment for the more prosperous members of middle classes and merchants, who were more interested in the social advancement of themselves and their descendants than in the productive investment of their capital in new enterprises. ${ }^{44}$ In the reign of Louis XIV, purchase of nobility by wealthy rotouriers increased, and this gave them possession of fiefs, exemption from the taille and extravagant lifestyle. Thus, provincial noblesse revived in the early $17^{\text {th }}$ century ancient and dormant custom of derogation and declared the status of nobility as incompatible with trade. But, this did not discourage the 
ambitious merchants to acquire both the forms and substance of hereditary nobility by service to the crown, by marriage and by purchase of noble fiefs or legal offices. This prejudice against trade immobilized the capital and energies, not only of ancienne noblesse but also of the newly ennobled merchants, who in order to preserve their status, invested their commercial profits in office, land and government bonds and lived as rentiers. ${ }^{45}$ Social attitudes did create an important obstacle in the French commercial expansion, as this prejudice against trade alienated both the noblesse and the merchant interest from commerce. Thus, the sale of offices acted as a sponge that absorbed the energies of the French business world. The distinction between social status and trade was maintained by the prejudices of the noblesse and the merchants. This was in the personal interest of territorial expansion or military glory of Louis XIV. ${ }^{46}$ It may be concluded that there was lack of private initiative and capital investment in commercial expansion because the French state provided opportunities for investment which carried no risk with them and led to the social advancement of the bourgeoisie. Bernier tried to relate the Indian problem of blockade circulation of precious metals with ongoing lack of commercial investment by the French bourgeoisie. Thus, he gave a veiled warning against Louis XIV's policies, which created opportunities for bourgeoisie to invest in offices instead of commercial activities.

\section{Counteraction on European Commercial Competitors}

It was stated by Bernier that the existing competition, jealously and rivalry among the European East India Companies to establish commercial links with India. He pointed out that, "I suspect that our rivals have spread the impression at court (Mughal Court) that French belong to a King who is very powerful and that we are a warlike, domineering and turbulent nation ...it seems to me that it would, at the beginning, be a good thing to try to remove from the mind of Aurangzeb and the ministers every ground for fearing that we should one day become too powerful in these regions." companies always attempted to outdo each other for furthering their own personal commercial motives in India. Bernier suggested that the French should be conscious enough not to let their enemy spread rumors, stating "Dutch might not make it an excuse for making French hated... seeing us(French) supporting a man who passes for a pirate... all the Muhamadans being very regardful of these vessels, seeing that they carry their Hajis or Pilgrims to Mecca." 48 Bernier advised the Frenchmen to highlight the decline of the Portuguese and the Dutch, whose excessive profiteering and the use of force had ruined the pilgrimages to Mecca. He gave clear instructions to the Frenchmen that they should not over praise the French monarchy by portraying Louis XIV as greater than the king of England, Portugal, Denmark or Holland. 
Several instructions were given by Bernier that not to reveal, and perhaps, even deny that the Louis XIV had subscribed one-fifth of the capital share in the French East India Company. ${ }^{49} \mathrm{He}$ suggested for "making a moderate show in the embassy to Delhi and that for this reason it would be enough if either Monsieur Carron or Monsieur de Faye went there alone. He said one should send only embassies of Frenchmen to India and Persia simultaneously, which might remove the cause of jealousy of the king of Persia." ${ }^{, 0}$ This kind of information was very significant for the Frenchmen to demonstrate their right image in the Indian courts, extract commercial benefits from the Indian monarch, and counteract the diplomatic measures of the European rivals.

\section{Role of Gifts and Bribes in India}

Vital information was provided by Bernier to the Frenchmen about the prevailing customs and traditions in India that one should know before establishing commercial contact with the Indians. Bernier said "My lord(Colbert), the greats were never approached empty-handed," ${ }^{, 51}$ as he described his personal experience that "when I had the honour to kiss the garment of the great Mogol Aureng-Zebe(Aurangzeb), I presented him with eight roupies, as a mark of respect; and I offered a knife-case, a fork and a pen-knife mounted in amber to the illustrious Fazel-kan (The Accomplished Knight), a minister charged with the weightiest concerns of the empire, on whose decision depended the amount of my salary as physician." 52 Bernier suggested that offering presents to the emperor was mandatory, but the extent of reciprocal favours from the royal recipient depended on, how cleverly and intelligently the Frenchmen presented them. He gave the example of Dirk van Adrichem, who was the chief or director of the Dutch factory at Surat from 1662 to 1665 . With an astute mind, he succeeded in obtaining a concession from Aurangzeb on $29^{\text {th }}$, October 1662 by presenting gifts, getting accustomed to the Indian customs before-hand and conducting himself accordingly. This helped him in securing valuable privileges for the Dutch in Bengal and Orissa. ${ }^{53}$ In another example, Bernier demonstrated that presents were also given by the Indian nobles to the Indian king for getting favours. He stated, "Jemla ${ }^{54}$, who had by his address contrived to obtain frequent invitations to the court of Chah-Jehan,...carried the most magnificent presents, in the hope of inducing the Mogul to declare war against the King of Golkonda and Bijapur and against the Portuguese...he presented Chah-Jehan with that celebrated diamond which has been generally deemed unparalleled in size and beauty" ${ }^{55}$ which was most probably 'Koh-i-nur. ${ }^{56}$

It was explained by Bernier that it was not just the ambassadors who were bound to present gifts to the monarch, but omrahs or Indian nobles were also compelled by custom to present magnificent gifts to the king during the festivals and on anniversaries. Bernier informed "an ancient custom attends 
these anniversary days of rejoicing, not at all agreeable to the omrahs. They are expected to make a handsome present to the king, more or less valuable according to the amount of their pay." ${ }^{57}$ Some of omrahs used this occasion to bribe the king and get personal favours fulfilled. They used the "opportunity of presenting gifts of extraordinary magnificence, sometimes for the sake of an ostentatious display, sometimes to divert the king from instituting an inquiry into the exactions committed in their official situations or governments and sometimes to gain the favour of the king and by that means obtain an increase of salary." ${ }^{, 58}$ Bernier also revealed that extraordinary amounts of presents were given to the influential royal Mughal princesses to get their favours. Begum-Saheb ${ }^{59}$ "accumulated great riches by means of her large allowances and of the costly presents which flowed in from all quarters." 60

Some foreign ambassadors ${ }^{61}$ were even more cunning as they "obtained money in return for their presents and gained still more considerable sums by means of the numerous horses, and different articles of merchandise, which they introduced into the kingdom free of all duty, as property belonging to ambassadors. With these horses and merchandise, they purchased the manufactures of Hindoustan, which they also claimed the privilege of taking out of the kingdom without the payment of the impost charged on all commodities exported."62 Ambassadors were honest spies under the guise to lie for their King and their country. They were believed to be the official intelligence gatherers who tried to collect information about roads, mountain passes, provisions, the size and equipments of the king's army etc. After the revolution ${ }^{63}$ in India, numerous foreign kings sent their ambassadors with magnificent gifts to acknowledge Aurangzeb's supremacy over India. ${ }^{64}$ They were searching for opportunities to establish alliances with the Indian kings against their common enemies. Presents and gifts played an essential role at the national and provincial levels. Bernier provided this highly essential information to Frenchmen about Indian customs and traditions. He also gave suggestions for the intelligent use of presents or bribes for extracting commercial benefits.

\section{Salam or Indian Act of Obeisance}

It was discussed by Bernier that the manner in which the ambassadors entered the court of Aurengzeb. Present in the audience, he witnessed "the ambassadors, when at a distance made a Salam, or Indian act of obeisance, placing the hand thrice upon the head and as often dropping it down to the ground. They then approached so near that Aureng-Zebe might easily have taken the letters from their own hands; ...the letters were presented to the king, who after having perused the contents with a grave countenance, commanded that," from head to foot: namely, a vest of brocade, a turban, and a sash or girdle, 
of embroidered silk." ${ }^{\prime 66}$ Bernier described the height of the submissiveness of the ambassadors. He said, "they came away from the audience delighted with their reception, without any feeling of mortification on account of the salam à l'Indien, which certainly savors of servility, and not at all displeased that the king had refused to receive the letters from their own hands. If they had been required to kiss the ground, or to perform any act of still deeper humiliation, I verily believe they would have complained without a murmur." "67 Bernier stated that "court officials will not prevent the Frenchmen during entering or leaving the court in king presence, without making salam, as it was not the French fashion; nevertheless, if after having received the serapahs ${ }^{68}$ or dresses,...I see no harm in doing it; all the more because I have never seen any ambassador who did not do it, unless it were the ambassador from Persia," 69 who came to India for the display of their wealth and honour. Bernier advised the Frenchmen about the prevalent Indian customs which should not be neglected such as, before entering the court one should know how to propitiate the doorkeepers adequately because if they were not given something then they "very badly ill-treated on entering the castle." 70 Therefore, Bernier advised the Frenchmen to give tips or presents to the guards and subordinates, for getting proper respect and avoiding undue interruption in their commercial operations.

\section{Significant Frenchmen for Embassies}

It was suggested by Bernier that the French embassies should give handsome and costly presents to the centre and not to forget to give a part of it to Jafar Khan, the Vizir. Pointing out the latter's importance, he stated, "the success of our business depends principally upon him and on him depends the weightiness, the tenor and the dispatch of those different firmans which are necessary for the establishment of factories and those letters of recommendation which, he may write to the governors of the provinces." ${ }^{, 71}$ Hence according to Bernier, these firmans were necessary for successful business and, the favours of chief officers should be won with the help of presents and promises.

Importance to the letter of recommendation was given Bernier, which every mercantile group "should not fail to take it from Jafar Khan before leaving Delhi, which is addressed to the ambassador of the Mogul who will be in Golkonda. This is a very needful thing for he is a devil and an avaricious knave, who for his own interests wishes that all business should pass through his hands." 72 This letter of recommendation from the "Governor if they offered any of their own accord, which they would be sure to do in order to show their importance and in the hope that we should remember them, but always remember to place reliance on no one but Jafar Khan." ${ }^{, 73}$ Bernier stated that it was almost mandatory to contact Jafar Khan in advance to make residential arrangements before the arrival of French ambassador at Agra. 
This French traveller suggested to give some presents to his son Namdar $\mathrm{Khan}^{74}$ and wife. "This man was much serviceable and did not hate the French, and, his wife was one of the most powerful, imperial and intriguing ladies of the court." ${ }^{, 75}$ Bernier further recommended discretion and secrecy in handling the political links, as there existed a great degree of jealously and enmity among these omrahs. Bernier advised his countrymen that "I think that it would almost be best not to go further than Jafar Khan and his households., 76

Some persons were refer by Bernier who could be of use to the Frenchmen in establishing commercial links with India. He gave an elaborate description of the relations shared by them among each other. This kind of information must have proved crucial to the French East India Company that had strong desires to establish links with India. Bernier stated that the recourse to Danechmend ${ }^{77}$ and Dianatkan ${ }^{78}$ should be taken only in the case of extreme urgency, and, only when Jafar khan wanted to delay the affairs intentionally. He suggested that close links with both the parties be maintained and they be kept happy.

\section{Importance of the Interpreter}

Bernier stressed the importance of a good interpreter for making the French business in India successful, facilitating their correspondence with Indians, and, extricating Frenchmen from various difficult and disagreeable situations. He stated that they (i.e. French) "need a good and faithful interpreter, thoroughly experienced and familiar with the customs and practices in the country and protocol at the court of Babar." ${ }^{, 79} \mathrm{He}$ advised that every means should be adopted to hire good interpreters because they were really necessary for the embassies sent to Delhi, Golkonda and neighbouring areas where the Frenchmen intended to establish their factories. ${ }^{80}$ Bernier stated the interpreter should be competent enough to read and write in various languages. He suggested the names of interpreters for different regions such as Jean-Baptiste Chomber for Aurangabad, born of French parents, and competent in different languages; Signor Iakimo, son of a Frenchman competent in Indian, Persian and Portuguese languages for Agra, and Monsieur saint Jacques, a Frenchman for the Delhi durbar. These interpreters should be employed carefully, enticed with presents and handled cleverly and tactfully so that they must not attempt to be the master of there own, but work according to the directions of superior authorities.

It was suggested by Bernier that for benefit of the French business in India, every French embassy should "have a man at court with whom we are in correspondence to keep a hand on our business so as not to be obliged to send special messengers whom they will always want to devour there as soon as they see them." ${ }^{81} \mathrm{He}$ also pointed out that the royal firmans from the centre played a significant role in establishing commercial bases in the 
provinces. These firmans prevented the corrupt governors and the officers from exacting money from the commercial merchants. Dutch commercial explorers mention that "the great difficulty of doing business in India is not in the sale or purchase of goods, men of moderate intelligence soon master that, but rather in knowing how to protect oneself from the exactions of the governors of provinces and the self-possessed and greedy scoundrels, their officials." ${ }^{, 2}$ This information is also corroborated by the later traveller who as an "alien merchant, was forced to fend for himself alone against a formidable array of "rascals". ${ }^{83}$ Frenchmen on their part found dealing with local merchants who were well entrenched in the trade of the Indian Ocean a difficult affair. Bernier probably mentioned this problem to create awareness about the complicated system of the French internal custom barriers such as tolls on roads, bridges and rivers with high cost of transportation, and custom duties levied by tax-farmers on all goods passing from one province to another. This was a major obstacle in the French commercial progress.

\section{Patience and Self-Control in Indian System}

Bernier informed about yet another practice of the Mughal Emperors, a "habit of detaining all ambassadors as long as can reasonably done, from an idea that it is becoming his grandeur and power, to receive the homage of foreigners and to number them among the attendants of his court." suggested that the French temper and pride should be controlled and, the ambassadors should not insist that the Indian emperor take the letter personally from them. Bernier demonstrated the differences in religion of the Frenchmen who believed in Christianity and the Indian Muhamadans who believed in Islam. He suggested that these religious differences should be considered before undertaking any commercial activity. Bernier told Frenchmen to "get it clearly into your head that they are Muhamadans and we Christians and that in consequence they hate us at least as much as we hate them." 85 Every French embassy and merchants should need to have extra-patience, self-control, prudence and mastery over the French temper in dealing with Indians. He said that the people of India were "cold and slow by nature there is no place in the world where business goes so slowly, they think their honour and dignity are concerned in keeping the ambassadors waiting at court as if the king and noblemen were always occupied in more important business; they think that with time they will always be able better to discover the temper and the designs of the visitors and then finally, one would say that they pretended to despise strangers so as to impress upon the minds of their subjects an idea of their own greatness...." ${ }^{\prime 86} \mathrm{He}$ advised the Frenchmen to have self-control in the oriental world for their successful commercial operations. 


\section{Identification of Commercially Significant Persons}

Bernier identified individuals, who could be used for the French commercial expansion in Golkonda. These people were, firstly, "Haknatsar, a Persian, by caste an Armenian, who... himself a Muhamadan, but none the less always love and supports Armenians. He has great opportunities of access to the secretary and even to the king and is a great intriguer, but one should take care in his own interest not to be on good terms with the Dutch. If one wishes to use Haknatsar, which would not be amiss, because he is as it of the household of the secretary, we should none the less be on our guard not to surrender the whole business into his hands...we ought only to beg him as our friend to give a satisfactory particularly and to promote and speed our business." 87 Second, person was an "ambassador of the Mogol, who, as they say, plays the little king there; but he is very much governed by selfinterest... If one wishes to use ambassador of the Mogol...we should take good care not to place the matter entirely in his hands, not only because there is always some jealousy on the side of the secretary if he sees that he has any hand in it, but because... he is a man who from self-interest may do anything. We ought then to have the wisdom to have him as our friend, was it only so that he might do no harm and for the rest direct our business towards the secretary." 88 Bernier highlighted the mutual relationship shared by these persons which was vital to get further benefits from the secretary of Golkonda. Lastly, he also proposed solution to the problem arising out of the dishonest conduct of the secretary, stating that "if the secretary was not acting honestly and that our business was being delayed, there is one great remedy, and that to go straight to Neikam Khan, the army general of the army, to make him understand thoroughly in writing our motives and to beg him to lend us his favour against the man oeuvre of ours rivals." About Neikam Khan, Bernier opined, "he was a man of great influence and was much devoted to the good of the state, who does not care a rap for the secretary or for anyone, and who goes to speak to the king when he thinks it right." 89

This French traveller also commented on the profits amassed by the Dutch factory in Golkonda by virtue of its commercially strategic location. He stated that "the factory of the Dutch at Golkonda is one of the best in the whole of Indostan, partly because of the great quantity of cloth and big chintzes which can be bought cheap thereabouts and taken to Masulipatam and partly because that is the meeting place of all the diamonds." 90 The Dutch factory was set up by intrigue and intelligence of Narson $d u$ Couratier, who was an opponent of the France. ${ }^{91}$

Bernier showed different means which should be adopted to establish a factory in Masulipatam, where Dutch were hated. French needed to give some decent gifts to the governor and, further, tempt him with more such presents. In Masulipatam, Bernier made mention about a Francophile 
person called "Monsieur Junet, a French merchant trades there by the favour of the English, he is extremely well versed in trade of the country and as his heart is thoroughly French and because he hopes much from French support, he can be of great service." 92

It was suggested by Bernier that Patna was another place where the French could establish their factory. He stated that from there "great quantity of saltpeter was extracted, as both the Dutch and the English had their factories, at seven to eight leagues away from the city, their the saltpeter is prepared in order to send it down from there on the Ganges to Bengal of Hugli, where load vessels with it for Europe." $" 93$ In spite of this advantage, Bernier opined that "I do not think it advisable to establish a factory there so early, all the more because one can find means, easily enough, to have saltpeter brought from there to Hugli or Qasimbazar... One should send some presents to the Governor of Patna, named Laskar Khan, and assure him that as soon as our ships should have come into Bengal we should come beneath his favour and to build there a factory." ${ }^{94}$ According to Bernier, in Patna, one person, who could be of some use, was Consabel, a Portuguese, who would be willingly given all possible information.

Bernier stated that in order to establish a factory in Bengal, one needed to send certain gifts to "the governor named Shaista Khan", because the Governors of Kasimbazar and Hugli are subordinate to him." suggested "we need to give him good presents because he is self-interested and his goodwill is absolutely necessary, so much so that being the uncle of the King." ${ }^{, 97}$ Shaista Khan should also be made to understand the motives of French to come to India. Bernier pointed out the importance of Bengal in his answer to the enquiry of Jean de Thevenot (1633-1677). He wrote that Bengal "produces rice in such abundance ...exported (it) to Ceylon and Maldives;... it provide sugar to Kingdoms of Golkonda, Karnatic, Arabia, Mesopotamia and Persia;....sugar, sweetmeat, fruits...article of considerable trade." 98 Bengal possessed large amounts of valuable commodities which attracted foreign merchants; these commodities were sugar, cotton and silk. Bernier mentioned that large quantities of cotton cloths, of different types and colours were exported by the Hollanders to many countries, especially to Japan and Europe. For the silk stuff, he mentioned that large quantities were drawn from Bengal for supplying to the entire Mughal Empire and many foreign countries. Another commodity of importance was saltpeter, which was imported from Patna ${ }^{99}$ to Bengal, from here Dutch and English sent large cargos to many parts of India and to Europe. Bernier advised that it was in this fruitful kingdom, that the best lac, opium, wax, civet, long pepper, and various drugs were obtained and butter was exported to a number of places. According to Bernier, Bengal was the store house of merchandise for the India, Europe and other countries.

Finally, Bernier suggested that "it will nevertheless be expedient for us to build our first factory at Kasimbazar, because that is the spot where all the silks (Dutch and English, silk factory had eight hundred native employees at 
Kasimbazar) and other merchandise come together, and that from Hugly, where the big ships come, there is a canal which goes from Kasimbazar, on which little boats can go, and that by land one can go there comfortably in three days." A small warning given by Bernier, to the persons going to Kasimbazar "must make up their minds from the first to be badly lodged."101 These suggestions must have helped Colbert to establish French factories at Surat (1668), Maulipatam (1669) and at Pondicherry (1673).

This piece of information was probably highlighted to draw attention of Louis XIV's government towards the deteriorating condition of French factories. The French factories demanded adequate support, proper direction and appropriate intervention from the state, but it lacked the financial support as bourgeoisie invested in land, rents and offices rather than in trade and industry. And whatever surplus was collected by the industrial reforms of Colbert, it was used to support Louis XIV financially for his ambitious foreign policies which stressed on political glorification rather than commercial expansion. It showed how the political and commercial interests varied but the combination of the two could play a positive role in the progress and development of the society.

\section{Indian Workshops and Karkhanas}

Actual conditions of the Indian workshops and Karkhanas were conveyed by Bernier to Colbert. He stated that the Indian workshops were occupied by the skilful artisans and praised their workmanship. He wrote that "numerous are the instances of handsome pieces of workmanship made by persons destitute of tools, and who can scarcely be said to have received instruction form a master. Sometimes they imitate so perfectly the articles of European manufacture that the difference between the original and the copy can hardly be discerned...Indians make excellent muskets, and fowling-pieces and such beautiful gold ornaments." ${ }^{102}$ Bernier admired the beauty, softness and delicacy of their paintings and miniatures and, was particularly struck with the exploits of Akbar, painted on a shield by a celebrated artist, who was said to have taken seven years in completing the picture. Bernier also highlighted the pathetic conditions of the Indian artisans. He said that "if the artists and manufactures were encouraged, the useful and fine arts would flourish; but these unhappy men are condemned, treated with harshness and inadequately remunerated for their labour." ${ }^{103}$ Bernier also gave information about the Karkhanas, stating that, "large halls are seen in many parts called Karkanas or workshops for the artisans." 104 There were separate halls for different kinds of work.

Bernier came from the country where the slavery was practiced and social differences pronounced, he puzzled over India's fabled and complex caste system which divided people by birth and traditional occupation. ${ }^{105}$ Bernier showed the evidence of caste system prevalent in India. He stated "the 
embroiderer brings up his son as an embroiderer, the son of a goldsmith becomes a goldsmith and a physician of the city educates his son for a physician. No one marries but in his own trade or profession; and this custom is observed almost as rigidly by Mahametans as by the Gentiles, to whom it is expressly enjoined by their law."106 This information of caste based division in the Indian society would have certainly helped the French merchants and the French factory owners in hiring the artisans and workers at the minimum salaries. Bernier also drew attention of the French state towards the poor conditions of the French workers and artisans who were overburdened by taxes due to wars resulting from the Louis XIV's ambitious expansionist policies.

\section{Warning Against Indian Pirates}

An Advice was given by Bernier to the Frenchmen to be cautious from the pirates in India. Bernier wrote in his travel accounts that the kingdom of Arakan, "has harboured during many years by several Portuguese settlers, christian slaves or half-caste Portuguese and other Franks collected from various parts of the world. This was a place of retreat for fugitives from Goa, Ceylon, Cochin, Malacca and other settlements in the Indies." 107 The king of Arakan kept these foreign pirates as "guards for the protection of his frontiers from Mogols, and permitted them to occupy a seaport called Chatigon and made them grants of land. They were left unrestrained by the government of Arakan, so that they pursued the trade of rapine and piracy with their galleasses, supported by numerous arms, entered into branches of Ganges and ravaged the islands of Lower Bengal." 108 These pirates once made a "formal offer to the viceroy of Goa, a Portuguese, to deliver the whole kingdom of Arakan into his hands. Bastian Consalve was the chief pirate, who was so famous that he married the daughter of the king of Arakan." ${ }^{109}$ Bernier described the violent practices of pirates in Arakan, which forced the Mogols to guard the opening of Bengal, by keeping large bodies of troops and a fleet of galleasses. All these precautions did not prevent the ravaging of the Mogol territories. These pirates became more bold and skilful. They attacked with four or five galleasses, and captured or destroyed large number of galleys of Mughals. Mughals under Shaista Khan ${ }^{110}$ decided to capture kingdom of Arakan, and, thus, they collected large number of galleasses and other vessels of considerable tonnage and threatened to overthrow the pirates, if they did not summit to the authority of Mughals.

Aurangzeb gave warning to these pirates to leave the service of king of Arakan and join the Mughal army. ${ }^{111}$ These pirates revealed their eagerness to act in concert with the Mughal troops, joined in the attack and capture of Sondiva, an island that had fallen into the hands of the king of Arakan, and accompanied the Indian army from Sondiva to Chatigon. Shaista Khan drew these Portuguese pirates to Chatigon, where he kept them and their families 
in his power, an occasion for their services no longer existed; so he considered it quite unnecessary to fulfill a single promise, he had made. He refused to pay them and declared them as traitors, in whom it was a folly to confide; wretches who had basely betrayed the prince whose salt they had eaten for many years. These pirates proved to be greatly harmful to the Indian trade and the French were advised by Bernier to be alert to these difficulties.

Robbers in area of the Ajmer and Ahmadabad were referred by Bernier, who were called Koullys. He wrote, "these Koullys are the peasantry of this part of the country, and are the greatest robbers and altogether the most unprincipled people in the Indies." 112 Bernier also commented on the methods adopted by omrahs to protect themselves from robbers. $\mathrm{He}$ described how the omrahs protected their goods by "providing watchmen, who continually perambulate his particular quarters during the night, crying out Kaber-dar! Or Have a care! And there are guards posted rounds the whole army at every five hundred paces, which kindle fires, and also cry out Kaber-dar! Besides these precautions, the Cotoual, or Grand provost, sends soldiers in every direction, who especially pervade the bazaars, crying out and sounding a trumpet." ${ }^{113}$ In spite of these measures, the robberies were often committed. So, Bernier suggested that the Frenchmen be on constant alert and not rely too much on the vigilance of servants.

\section{Defensive Mechanism for Commercial Expansion}

A very significant advice was given by Bernier to the Frenchmen to form strong defense mechanisms to protect their Indian factories and dwellings. Bernier cited an example that the English and Dutch protected their dwelling from plunder of Shivaji in Surat because these people displayed a great deal of resolution and defended themselves well against their enemies. English were assisted by the crews of their vessels, and they performed wonders and saved not only their own houses but also those of their neighbours. ${ }^{114}$ Bernier gave significant details about the Indian defense system, starting from importance of ragipous ${ }^{115}$, omrahs ${ }^{116}$, mansebdars, rouzindars, common troopers, infantry, artillery and private soldiers. Bernier gave detailed narratives of decisive battles fought during the Shah Jahan's succession like Battle of Dharmatput, Battle of Samugarh and Battle of Khajwa. ${ }^{117}$ He gave substantial details of the deployment of troops on each side, the weapons employed, and, their commanders and their qualifications. This detailed account was no doubt intended for the European military leaders and for Colbert, who had the interest in the military strength, strategy employed and armaments used by indigenous powers as French East India Company might have to encounter it in near future. ${ }^{118}$

Bernier tried to show the weaknesses of the Indian defense system in comparison to French. He wrote, "paying the whole of this army every two 
months, from the omrah to the private soldier; for the king's pay is their only means of subsistence. In France, when the exigencies of the times prevented the government from immediately discharging an arrear of debt, an officer, or even a private soldier, may contrive to live for some time by means of his own private income; but in the Indies, any unusual delay in the payment of the troops is sure to be attended with fatal consequences; after selling what ever trifling articles they may possess, the soldiers disband and die of hunger." 119 These direct references to the tactics needed to correct the deficiencies of the Indian military system was in some way connected to the general and vague ambition of the French East India Company in establishing their colonies in India. ${ }^{120}$ Bernier probably tried to criticize Louis XIV's massive military operations and continuous warfare which were directed towards absorption of large amount of surplus and heavy burden of taxes on the whole society.

\section{Drawbacks of Significance of Bernier's Commercial Information}

Travel account's of Bernier contain exhaustive information about the trade and economy of the Mughal Empire, but at times it makes statements without proper verification of the facts. Similarly, they offer little direct help in investigating the causes of the fluctuations in the prices of gold, silver, copper and sometimes they confuse 'price' with old dam. They often fail to draw a fair picture of the price data of the necessary commodities. ${ }^{121}$ According to Stanley J. Tambiah, albeit Bernier was immensely impressed with the incalculable wealth of the Great Mughals, the gold and silver, varied goods that were imported and the equally varied goods that were exported in return, he says little about the institutions, arrangements and specialists, both indigenous and foreign, which must have made possible Hindoustan's arrears of manufactures and complex trade flows. ${ }^{122}$ All these European travellers directly or indirectly were involved in exploring trading possibilities within India. Some of these accounts could be termed as merchant guide books. ${ }^{123}$ On the whole, Bernier has sometimes given exaggerated accounts of the state of gold and silver deposits in India and also of the Mughal revenue collection. In his travellers' accounts, he had constantly used sycophantic language to appease the Frenchmen like Colbert and his friends.

\section{Conclusion}

It can be concluded that Bernier made an epoch-making contribution in describing the commercial possibilities of South-Asia to the French state. He gave significant details like commercial strongholds of other European companies in India and, gave vital information for scrutinizing the site for the French factory. He informed the Frenchmen about the court customs and superstitious ideas prevailing in India and, presented the geographical 
boundaries and marked important Indian ports; depicted the large amounts of gold and silver absorbed in India, and almost no outflow of these precious metals. He listed the amounts of Indian imports and exports to different countries and lastly, explained the condition of workers, artisans and Karkhanas. His travel literature might have helped Colbert and the French East India Company to establish links with the Indian commercial avenues in $17^{\text {th }}$ and $18^{\text {th }}$ century. On other hand, he gave a veiled warning to Louis XIV for giving more importance to establishing political hold than expanding commercial links. This finally led to the decline of the French trade in Indian seas as compared to the English in $18^{\text {th }}$ century. Colbert's mercantilist policies proved beneficial to establish economic stability and self-sufficiency in the France, but it could not withstand against the insatiable demands of Louis XIV's increasingly expensive wars. One should acknowledge the limitation of the travel accounts, but Bernier's pathbreaking travel accounts are a monumental work by any occidental traveller describing the oriental commercial avenues and suggesting ingenious solutions to the commercial problems of his native country. After making an assessment of Francois Bernier's travel account, it can termed that his account was simultaneously acting as a critic of French state and also a commercial informer for French state.

\section{References PRIMARY SOURCES}

Ball, V (trans.), Jean-Baptiste Tavernier, Travels in India, 1640-67, $2^{\text {nd }}$ ed. Revised by William Crooke, 2 vols., (London, 1925; rpt., Delhi: Low Price Edition, 2000).

Beveridge, H., (trans.) The Maathir-ul-umara: being biographies in 2 vols., by Shah Nawaz Khan, (Delhi: Low price edition, 1999).

Constable, Archibald (ed.), Francois Bernier, Travels in the Mogul Empire $A D$ 1656-1668, transl. on the basis of Irving Brock's version, $2^{\text {nd }}$ edition revised by V.A.Smith, (London: Oxford University Press, 1891; rpt. Delhi: Low Price Publication, 1994).

Fawcett, Sir Charles (ed.), The Travels of the Abbe Carre in India and the Near East: 1672 to 1674, 3 vols. (trans.) by Lady Fawcett.(London: Hakluyt Society, 1947; rpt. New Delhi: Asian Education Service, 1990).

Foster, William (ed.), The Embassy of Sir Thomas Roe to the court of the Great Mogoul 1615-1619, vol. I-II (London: Hakluyt Society, 1899).

-----Early Travels in India 1583-1619 (London: Oxford University Press, 1921; rpt. Delhi: Low Price Publication, 1999).

Grey, Edward (ed.), The Travels of Pietro della Valle in India: From the English Translation of 1664 of G.Havers: In Two Vols. (London: Hakluyt Society, 1892). 
Jhss, Vol. 1, No.1 , January to June 2010

Irvine, William (trans.), Storia do Mogor or Mogul India 1653-1708 by Niccolao Manucci, vols.4, (London, 1907; Delhi: Low Price Publications, 1990).

Ray, Aniruddha (ed.), Francois Martin Memoires: Travels to Africa, Persia and India 1664-70 (Calcutta: Subarnarekha, 1990).

Sarkar, Jadu Nath (trans. and ed.) Maasir-i-Alamgiri: A History of the Emperor Aurangzeb by Saqi Mustaidd Khan (Calcutta: Royal Asiatic Society of Bengal, 1947).

Sen, S.N. (ed.), The Indian Travels of Thevenot and Careri, (New Delhi: National Archives of India, 1949)

Syed, Anees Jahan (trans.), Aurangzeb in Muntakhab-ul Lubab by Muhammad Hashim Khafi Khan (Bombay: Somaiya, 1977).

Temple, Sir R.C. (ed.), The Travels of Peter Mundy in Europe and Asia, 1608-1667, 2 vols. (Cambridge and London: Hakluyt Society, 1907-36).

\section{SECONDARY SOURCES}

Ali, M. Athar, Mughal Nobility under Aurangzeb, (Bombay: Asia Publishing House, 1966; rpt. Delhi: Oxford University Press, 2001).

Ames, Glenn.J and Love, Ronald .S. (eds.), Distant Lands and Diverse Cultures: The French Experience in Asia 1600-1700 (Westport: Praeger, 2003).

Ames, Glenn J. "Colbert Indian Ocean Strategy of 1664-1674: A Reappraisal" French Historical Studies, vol. 16, no.3 (Spring 1990)

Anderson, Perry, Lineages of the Absolutist State (London: Verso, 1974).

Ansari, Mohammad Azar, European Travellers under the Mughals (15801627) (Delhi: IAD Oriental Series, 1975).

Beik, William, Absolutism and Society in Seventeenth Century France (Cambridge: Cambridge University Press, 1985).

Bendyhe, T., (trans.) Journal des Scavans, April 24, 1681. The new division of the earth, into the different species or races of men who inhabit it, send by the famous traveller to Mons. *****" Memoirs read before the Anthropological society of London" Vol 1, (1863-64)

Bernasconi, Robert, (intro and ed. note) in Bernier, Linnaeus and Maupertuis by Francois Bernier, in concepts of race in the eighteenth century, vol-1, (Bristol: Thoemmes Press, 2001)

Bernard, Lean, "French Society and Popular uprising under and Louis XIV," French Historical Studies, Vol.3, No 4 (autumn, 1964).

Boulle, Pierre H., "François Bernier and the Origins of the Modern Concept of Race," in Sue Peabody and Tyler Stovall (ed.) The colour of Liberty histories of Race in France, (Durham: Duke University Press, 2003),

Burke, Peter, "The Philosopher as Traveller: Bernier Orient," in Jas Elsner and Joan-Pau Rubies (eds.), Voyages and Visions: Towards a Cultural History of Travel (London: Reaktion Books, 1999). 
Burns, Edward MacNall Burns, Philip Lee Ralph, Robert E.lerner, and Standish Meacham. World Civilizations: Their history and their Culture, Vol B. (New York: 1986; W.W. Norton and Company, Inc; $1^{\text {st }}$ Indian ed Delhi, 1991).

Carsten, F.L., (ed.), In The New Cambridge Modern History: The Ascendancy of France 1648-88, vol. V, (Cambridge: Cambridge University Press, 1961; rpt., 1975).

Chandra, Satish, Medieval India: From Sultanat To The Mughals, Part two Mughal Empire. (1526-1748), (Delhi: Har-Anand Publications, 1999), Chaudhuri, Tapan Ray and Irfan Habib, (eds.), The Cambridge Economic History of India c. 1200-1750 (Cambridge: Cambridge University Press, 1982).

Chaudhury, Sushil, "A Note on Sati in Medieval India" Proceedings of IHC, (1964).

Cipolla, Carlo. M. (ed.), Fontana Economic History of Europe: Sixteenth and Seventeenth centuries, Vol 2, (London: Collins/Fontana, 1974).

Collins, James B, The State in Early Modern France, (New York: Cambridge University Press, 1995).

Coveney, P.J. (ed. \& trans.), France in Crisis 1620-1675 (London: Macmillan and Co., 1977).

Dasgupta, Ashin, Indian Merchants and the Decline of Surat 1700-1750 (Wiesbaden: Franz Steiner, 1979).

Dufrenoy, M. L., "A Precursor of a Modern Anthropology: Francois Bernier (1620-1688)." Isis, Vol. 41, No. 1 (Mar, 1950).

Fisher, Michael H., (ed.), Beyond the Three seas: Travellers' Tales of Mughal India (New Delhi: Random House, 2007).

Grassy, R.B, "Social Status and commercial enterprise under Louis XIV." The Economic History Review, New Series, vol. 13, No 1 (1960). pp. 19-38.

Goubert, Pierre, (ed.) The French peasantry in the Seventeenth century. trans. by Ian Patterson. (New York: Cambridge University Press, 1987).

Habib, Irfan, The Agrarian System of Mughal India 1556-1707, (Delhi: Oxford University Press, 1963; rpt.1999).

Delhi: Tulika Books, 1995).

-Essay in Indian History, Towards a Marxist perception (New

Hazard, Paul, The European Mind (1680-1715). (England: Pelican Books, 1964; rpt. London: Penguin Univ. Books, 1973).

Husain, Ruquisya K. "Danechmend Khan- A Scholarly Noble at the Mughal Court" Proceedings of IHC (1997).

Jackson, J. Hampden, A short history of France from early times to 1972, (Cambridge: Cambridge University Press, 1974).

Kaur, Jaspinder, "European perception of the Indian Health Sytem: Italian Niccolao Manucci's observation," Indian Horizons, Vol. 52 Winter issue p. 57-62

Kaul, H.K. (ed.) Travellers India: An Anthology (New Delhi: Oxford University Press, 1979). 
Jhss, Vol. 1, No.1 , January to June 2010

Lafont, Jean-Marie, Indika, Essays in Indo- French Relations, 1630-1976, (Delhi: Monahar Publishers. 2000).

Eighteenth century" Seminar proceedings. Indo-French Relations: History and Prespectives, New Delhi, 17-19 April, (1990).

Lal, Ruby, Domesticity and Power in the Early Mughal World. (Cambridge: Cambridge University Press, 2005).

Misra, Rekha, Women in Mughal India: 1526-1748, (Delhi: Munshiram Manoharlal Oriental Publishers and Booksellers, 1967).

Morison, Theodore. (trans.) "Minute By M.Bernier upon the Establishment of Trade in the Indies, Dated $10^{\text {th }}$ March, 1668"Journal of the Royal Asiatic Society, 1933.

Moreland, W.H, From Akbar to Aurangzeb: A study in Indian Economic History. (London: Macmillan, 1923; rpt. New Delhi: Oriental, 1972).

Mustafa, Khursheed, "Travel in Mughal India." Medieval India Quarterly, Vol III, (Aligarh, 1958).

Nanda, Meera, European Travels Accounts During the Reign of Shahjahan and Aurangzeb, (Kurukshetra: Nirmal Book Agency, 1994).

Oaten, Edwary Farley, European Travellors in India, During the Fifteenth, Sixteenth and Seventeenth Century (London, 1909; rpt. Lucknow, Pustak Kendra, 1973).

O'Leary, Berndon, The Asiatic mode of production, (Oxford: Basil Blackwell, 1989).

Paranjape, Marakarand, "Pilgrims and other Travellers" India International Centre Quarterly Spring (1999).

Parker, David, "Absolutism, Feudalism and Property Rights in the France of Louis XIV." Past and Present a Journal of Historical Studies No 178-179, (2003), pp. 60-97.

Pearson, M.N.,'The Thin end of the Wedge, Medical relativities as a Paradigm of Early Modern Indian-European relations' Modern Asian Studies 29,(1995), pp.141-170.

------------The Portuguesse in India (New York:Cambridge University Press, 1987)

Phukan, Meenaxi, Rise of the Modern West: Social and Economic History of Early Modern Europe (Delhi: Macmillan India Limited, 1998).

Prasad, R.C, Early English Travellers in India. (Delhi, 1965).

Price, Roger, A Concise History of France. (Cambridge: Cambridge University Press, 1993).

Ray, Aniruddha Ray, "Last Memoir of Francois Bernier from Surat March 10,1668" Proceeding of IHC (1981).

---------- "French View of Slavery in Medieval India" Proceedings of IHC (1998).

-"The French Presence At Calicut from Mid Seventeenth to the early decades of the Eighteenth Century" Proceeding of IHC (1999). 
Ray, Indrani, 'The French Company and the Merchants of Bengal (16801730)' IESHR Vol VIII 1971 pp. 41-55.

D.V. Subba Reddy, "An account of Indian Medicine by François Bernier", Bulletin of the Department of History of Medicine, Osmania Medical college (Hyderabad) India. vol. II, No. 1, (Jan,1964), pp. 42-53.

Ryazanskaya S.W. (ed.), Marx and Engel: Selected Correspondence (Moscow, 1955).

Said, Edward W, Orientalism (England: Routledge \& Kegan Paul Ltd, 1978; rpt. England: Penguin Books, 1991).

Sarkar, J.N. History of Aurangzeb, 5 vols, (Bombay: Orient Longman, 19724).

Sharma, D.C. (eds.), Aurangzeb in Kashmir: Bernier Francois (New Delhi: Rima Publishing House, 1998).

Sinha, Arvind, "French Trade in India in XIII century' in Seminar proceedings. Indo-French Relations: History and Prespectives, 17-19 April, (New Delhi, 1990).

Subramaniam, Lakshmi, The French East India Company and the Trade of the Indian Ocean, A collection of Essay by Indrani Ray. (Delhi: Munshiram Publishers, 1999).

Subrahmanyam, Sanjay, Explorations in Connected History, From to Tagus to the Ganges. (New Delhi: Oxford University Press, 2005).

-----------Explorations in Connected History, Mughals and Franks (New Delhi: Oxford University Press, 2005).

Tambiah, Stanley J., "What did Bernier actually say? Profiling the Mughal Empire," in Veena Das et al. (eds.), Tradition, Pluralism, and Identity: Essays in Honour of T.N. Madan (New Delhi: Sage, 1999).

Teltscher, Kate, India Inscribed, European and British Writing on India 1600-1800, (Delhi: Oxford University Press, 1995).

Vincent, Rose, (ed.) The French in India: From Diamond Traders to Sanskrit Scholars. trans., Latika Padgaonkar. (Bombay: Popular Prakashan, 1990).

Wahi, Tripta, "The European Background to Bernier Travels." Proceedings of IHC (Patila, 1967).

Wheeler, J.Talboys, Early Travels in India $16^{\text {th }}$ and $17^{\text {th }}$ centuries, (Delhi: Deep and Deep Pub., 1975).

Zaidi, S.Inayat A., "French Mercenaries in the Armies of South Asian states, 1499-1803 A.D." Seminar proceedings. Indo-French Relations: History and Prespectives, 17-19 April, (New Delhi, 1990).

Zaidi, Sunita, "Women through ages" in Diplomatist Magazine, 2005.

Zaidi, Sunita, "Women: A symbol of Cultural Subordination" Paper presented to International Seminar on Culture, Economy and Social Change in Medieval India. $12^{\text {th }}$ to $17^{\text {th }}$ century. Centre for Advanced Studies in History, AMU, Aligarh, 5-7 January, 2002. 
${ }^{1}$ Nanda, European Travels Accounts during the reign of Shahjahan and Aurangzeb, p. 52 .

2 J.B. Tavernier. Travels in India, English tr. V. Ball, $2^{\text {nd }}$ ed. Revised by William Crooke, 2 vols., (London: 1925; rpt., Delhi: Low Price Edition, 2000): hereafter cited as Tavernier, Travels in India.

${ }^{3}$ Surendranath Sen (ed.) Indian travels of Thevenot and Careri, (New Delhi: National Archives of India, 1949).

${ }^{4}$ Sir Jean Chardin, the celebrated French traveller, was born in Paris in 1643, and died in London 1713. His Journey was to Persia and India in 1665 and while there he received the patronage (his business was that of a jeweller) of Shah Abbas. Chardin was in Surat in 1667 and in 1677, and it must have been in 1667 that Bernier met him there; as we know from the date of this letter to Monsieur Chapelain that Bernier was in Shiraz in October 1667.

${ }^{5}$ Francois Martin, India on the $17^{\text {th }}$ century(Social, Economic and Political): Memoirs of Francois Martin (1670-1694); English tr. and Annotated, Lotika Varadarajan., (Delhi: Manohar, 1983)

${ }^{6}$ Sir Charles Fawcett and Richard Burn (eds.), tr. Lady Fawcett, The Travels of the Abbe Carre in India and the Near East:1672 to 1674, 3 vols. (London: Hakluyt Society, 1947; rpt., New Delhi, 1990). Note: Abbe Carre was sent by Louis XIV and his able minister, Colbert, to support the recently started French trade in India. Carre was evidently a kind of spy to watch the activities of the French East India Company and submitted reports to Colbert on its affairs.

${ }^{7}$ Jean Baptiste Colbert was the Finance minister of France during 1664-1683. "Colbert took different mercantilist measure in France like establishing interest rate no higher than $5 \%$ and removed middlemen; he tightened the process of centralized system for tax collection (taille), he also made measures to blockade the exemption for nobles and clergy from taille and the corrupt officials were removed which helped in reaching of tax collection into royal treasury. He discouraged importation of foreign goods by imposing tariffs into France and improving means of commerce for transport. Colbert boosted the domestic industries by improving the quality of French manufactured goods by minute regulations. He awarded royal privileges, monopolies, subsidies, interest free loans and tariff concession to state supported industries to increase the range and output of French industries." (Burns, World Civilization. pp. 826-827).

${ }^{8}$ Edward Burns, MacNall Burns, Philip Lee Ralph, Robert E.lerner, and Standish Meacham, (eds.) World Civilizations: Their history and their Culture, vol B., (New York: W.W. Norton \& Company, 1986; rpt. Delhi: Goyl Saab, 1991), p. 827: hereafter cited as Burns, World Civilization.

${ }^{9}$ Burns, World Civilization, p. 790. .

${ }^{10}$ In other words, we can say that there was continuing primacy of the aristocrats over the bourgeois priorities in the French government and society.

${ }^{11}$ Sir Theodore Morison, "Minute by M. Bernier upon the Establishment of Trade in the Indies, dated $10^{\text {th }}$ March, 1668" in Journal of the Royal Asiatic Society., Part I, January (1933) p.1-21

12 Bernier, Travels, p. 201.

${ }^{13}$ Tavernier, Travels in India, pp. xxiii-xxiv; Tavernier also used flattering language for the Louis XIV (Tavernier, Travels in India, p. lxix).

${ }^{14}$ Bernier, Travels, p. 200.

${ }^{15}$ Morison, "M.Bernier", p.1-21. Note: Carron had founded the first French factory in India in 1668, after twenty years of leaving the Dutch service. 
${ }^{16}$ Bernier, Travels. p.461. Note: Licence to Tavernier's accounts was also given by Louis XIV. Printed for the first time on $1^{\text {st }}$ October 1676. (Tavernier, Travels in India, $p$. 327).

${ }^{17}$ Bernier, Travels, pp. xlv-xlvi. Note: Translation of Bernier's Dedication to King Louis XIV of France, from the 1670 Paris edition. He directly dedicated his travel accounts to Louis XIV, and requested for pardon from His majesty for his language. (Bernier, Travels, pp. xlv-xlvi.)

${ }^{18}$ Bernier, Travels, p. 223

${ }^{19}$ Bernier, Travels, pp. 455-458.

20 Irfan Habib, Agrarian system of Mughal India 1556-1707 (New Delhi: Oxford University Press, 1963; revised $2^{\text {nd }}$ ed., OUP: Delhi, 1999).

${ }^{21}$ J. Lough, "France Under Louis XIV," in F.L. Carsten (ed.), The New Cambridge Modern History, The Ascendancy of France 1648-88, vol-V, (Cambridge: Cambridge University Press, 1961; rpt. 1975), pp. 222-247. hereafter cited as Lough, "France Under Louis XIV".

${ }^{22}$ Bernier, Travels, p. 268.

${ }^{23}$ Ibid, p. 268.

${ }^{24}$ Versailles was hailed as the 'abode of the Sun King' with his proud motto Nec pluribus impar (greatest of all); its very doors bore in gold, the emblem of his greatness. (Carsten, The Ascendancy of France, pp.239-240).

${ }^{25}$ Lough, "France Under Louis XIV," pp. 222-247. Note from J. Hampden Jackson, A short history of France from early times to 1972, (Cambridge: Cambridge University Press, 1974), p. 61

${ }^{26}$ Benier, Travels, pp. 213, 223.

${ }^{27}$ Ibid., p. 223.

${ }^{28}$ Ibid., p. 222.

${ }^{29}$ Bernier, Travels, pp. 202-204.

${ }^{30}$ Ibid., p. 204.

${ }^{31}$ Bernier, Travels, p. 204.

${ }^{32}$ Bernier, Travels, p. 204.

${ }^{33}$ Carsten, The Ascendancy of France, p. 34

34 D.C. Coleman, "Economic problems and policies," in F.L.Carsten (ed.), The New Cambridge Modern History, The Ascendancy of France 1648-88, vol.V, (Cambridge: Cambridge University Press; 1961; rpt. 1975), pp. 19-46. Hereafter cited as Coleman, Ascendancy.

${ }^{35}$ Bernier, Travels, p. 223.

${ }^{36}$ Bernier mention enormous expenses of the Mughal seraglio, where there was huge consumption of fine cloths of gold and brocades, silks, embroideries, pearls, musk, amber and sweet essences.

${ }^{37}$ Bernier, Travels, pp. 223-224.

${ }^{38}$ Bernier, Travels, pp. 224-225.

${ }^{39}$ Note: Gentiles referred to Hindus.

${ }^{40}$ Bernier, Travels, pp. 225-226.

${ }^{41}$ Tavernier, Travels in India, p. 159.

${ }^{42}$ Bernier, Travels, p. 226.

${ }^{43}$ Carsten, The Ascendancy of France, pp. 17-18.

${ }^{44}$ Lough, "France Under Louis XIV," pp. 222-247.

45 R.B.Grassy, "Social Status and commercial enterprise under Louis XIV." The Economic History Review, New Series, vol. 13, No 1 (1960), pp.19-38.

${ }^{46}$ Phukan, Meenaxi, Rise of the Modern West. Social and Economic History of Early Modern Europe, (Delhi: Macmillan India Limited, 1998). 
${ }^{47}$ Morison, “M.Bernier", p. 2.

${ }^{48}$ Ibid., p. 2.

${ }^{49}$ Ibid., ft. 1, p.3,

${ }^{50}$ Ibid., p. 3.

${ }^{51}$ Bernier, Travels, p. 200.

${ }^{52}$ Ibid., p. 200.

${ }^{53}$ Ibid., p. 127.

54 Mir Muhammad Said Ardistani, surnamed Mir Jumla and afterwards entitled Muazzam Khan, Khan Khanan Sipah Salar, was born in Ardistan near Ispahan, and came to India as the personal attendant of a Persian merchant. It was in 1656 that he managed to gain favour, protection and patronage of Shah Jahan. After the accession of Aurangzeb he was appointed as the governor of Bengal and died at Khizarpur in Kuch Behar in 1663 after his return from an expedition against the kingdom of Assam. (Bernier, Travels, ft. 3, pp.16-17).

${ }^{55}$ Bernier, Travels, p. 22.

56 Tavernier, Travels in India, pp. 331-346. Note: Detailed description of Koh-i-nur diamond has been given by Tavernier.

${ }^{57}$ Bernier, Travels, p. 271.

${ }^{58}$ Ibid., p. 271.

${ }^{59}$ Begum-Saheb was the eldest daughter of Shah Jahan. She was very beautiful and very close to Shah Jahan. Bernier, expressing the views of some Mullahs or doctors of law about the relations between Shah-Jahan and Begum Saheb, stated, "it would have been unjust to deny the King the privilege of gathering fruit from the tree he had himself planted." (Bernier, Travels, p. 11).

${ }^{60}$ Bernier, Travels, p. 12.

${ }^{61}$ Note: These embassies came from Mecca, Bassora, Yemen, and Abyssinia.

${ }^{62}$ Ibid, p. 134.

${ }^{63}$ Revolution was the coup d'état of Aurangzeb to the Mughal throne.

${ }^{64}$ Bernier, Travels, p. 117. Note: These ambassadors were send to perform the ceremony of the Mobarek, "to express in a solemn manner their wishes that his reign might be long and auspicious."

${ }^{65}$ Ibid., pp. 117-18.

${ }^{66}$ Ibid., p. 118.

${ }^{67}$ Ibid., p. 119. They are referred to usbec ambassadors.

${ }^{68}$ Serapah means the gift like brocade, a turban, and a silk sash, embroidered with gold and silver.

${ }^{69}$ Morison, “M.Bernier", p. 9.

${ }^{70}$ Ibid., p. 9. Bernier calls these doorkeepers as rascals, who showed their insolence to the strangers.

${ }^{71}$ Ibid., pp. 3-4. Jafar Khan, entitled Umdat-ul-Mulk, was appointed Prime minister by Aurangzeb in 1662 and died in 1670 at Delhi. He was the son of Sadiq Khan, a cousin of Nur Jahan, he had married one of her sisters and hence was related to Aurangzeb. (Bernier, Travels. ft. 4. p. 271); Shah Nawaz Khan, The Maathir-ul-umar, tr. By H. Beveridge, vol. 1 (Delhi: Low price edition, 1999), pp. 722-723. hereafter cited as Beveridge tr., The Maathir-ul-umara.

${ }^{72}$ Bernier, Travels, p. 118.

${ }^{73}$ Morison, "M.Bernier", p. 10.

${ }^{74}$ Beveridge, The Maathir-ul-umara, vol. 2, pp. 378-381.

${ }^{75}$ Ibid., p. 4.

${ }^{76}$ Ibid., p. 4. 
77 Danechmend Khan was another influential person with the King from being able to speak with him when he thinks good and being his master and teacher and counselor; but Jafar Khan and he are not very good friends because Danechmend Khan carries it high, being the learned man of India... Jafar khan was allied to Mulla Sale representing as good Musalmans against Danechmend I have served him for so many years and as I know that he thinks very well of me... the purpose to remain on good terms and to make use of, in case of need, for the business of the Company."77 Bernier suggested that every Frenchmen be conscious of the internal rivalries among these omrahs. Therefore, it was necessary to deal with them intelligently in order to extract commercial concessions from both the parties.

78 "Dinanetkan,...he is very influential with the king, very ready to oblige and a great friend of the franks. He is a man who can say something privately to the king."78 His son, Rostan Khan, who was a friend of Europeans, and had influence on the king and can speak to him privately.

${ }^{79}$ Morison, "M.Bernier", p. 11.

${ }^{80}$ Note: Frenchmen intended to establish their factories at Patna, Bengal and Masulipatam.

${ }^{81}$ Morison, "M.Bernier", p. 12.

${ }^{82}$ Ibid., p. 12.

${ }^{83}$ Subramaniam, (ed.) The French East India Company and the Trade of the Indian

Ocean, p. 2.

${ }^{84}$ Bernier, Travels, p. 128.

${ }^{85}$ Morison, "M.Bernier", p. 13.

${ }^{86}$ Ibid., p. 14.

${ }^{87}$ Ibid., p. 17.

${ }^{88}$ Ibid., p. 17.

${ }^{89}$ Morison, "M.Bernier", p. 18.

${ }^{90}$ Ibid., p. 18.

${ }^{91}$ Ibid., p. 18.

${ }^{92}$ Ibid., p. 19.

${ }^{93}$ Morison, “M.Bernier". pp. 19-20.

${ }^{94}$ Ibid., p. 20.

95 Shaista khan was the uncle of Aurangzeb, the son of the wazir Asaf Khan and brother of Shah Jahan's wife Mumtaz Mahal; Beveridge, The Maathir-ul-umara, Vol. 2, pp. 825836.

${ }^{96}$ Morison, “M.Bernier", p. 20.

${ }^{97}$ Ibid., p. 20.

${ }^{98}$ Bernier, Travels, p. 438.

${ }^{99}$ One of the principal refineries of saltpeter was at Chaprah about 25 miles from Patna, where the French, Dutch and Portuguese had their factories. (Bernier, Travels, ft.2, p. 440).

${ }^{100}$ Morison, “M.Bernier", p. 21.

${ }^{101}$ Ibid., p. 2.

${ }^{102}$ Bernier, Travels, pp. 256-259.

${ }^{103}$ Ibid., pp. 228-229. These artists were payed less then they deserve and, their salaries usually depend upon the caprice of governor. Bernier described the feeling of artisan who feels discourage when he knows that he will never attain any distinction and will not be allowed to purchase either office or land for the benefit of his family. (Bernier, Travels, pp. 228-229).

${ }^{104}$ Bernier, Travels, p. 258. 
${ }^{105}$ Michael H.Fisher, Beyond the three seas: Travellers' Tales of Mughal India, (New Delhi: Random House, 2007), p. 5.

${ }^{106}$ Ibid., p. 259.

${ }^{107}$ Ibid., p. 174.

${ }^{108}$ Bernier, Travels, p. 175.

${ }^{109}$ Ibid., p. 178. Viceroy felt unpleasant to listen to the proposal of the pirates, as they felt disrespected to be indebt to a man of low origin. (Bernier, Travels, p. 175).

${ }^{110}$ Chah-hest- kan (Shaista Khan) undertook the expedition against the king of Arakan.

${ }^{111}$ Bernier, Travels, pp.181-82.

112 Ibid., pp. 88-89.

${ }^{113}$ Ibid., p. 369.

${ }^{114}$ Ibid., p. 189.

115 Bernier gave reasons why did Mughal were obliged to retain these Rajas in their services. Some reasons were like they were excellent soldiers, used against any revolt, they were employed against pathans or rebellious governors, and, they were employed against the Persians and Turks rebels. (Bernier, Travels, pp. 211).

${ }^{116}$ Bernier informed that the omrahs were given high titles by the king, and these high sounding titles were to deceive the foreigners. Their pay was in proportion not to the number of men they hold by to the number of horses they maintain. Two horses were generally allowed to one trooper. Aurangzeb himself regulates that minimum number of horses should be maintain by the omrah. (Bernier, Travels, pp. 210-215).

${ }^{117}$ Battle of Dharmatput was fought on $20^{\text {th }}$ April, 1658, in which Aurangzeb emerged victorious against the combined forces of Kasem Khan and Raja Jaswant Singh. Battle of Samugarh was fought on $28^{\text {th }}$ May, 1658 , in which Aurangzeb emerged victorious against Dara forces and, the battle of Khajwa was fought on $5^{\text {th }}$ January 1659 , in which Aurangzeb emerged victorious against Shuja forces. (Bernier, Travels, pp. 38, 49-54, 7678)

${ }^{118}$ Ames, The French Experience in Asia, pp. 147-162.

${ }^{119}$ Bernier, Travels, p. 220.

${ }^{120}$ Tripta Wahi, “The European Background to Bernier's Travels.” Proceeding of Indian Historical Congress, 1967, pp. 58-61. Note: Bernier's description of Indian military system, its strategies and armaments were probably intended to apprise the French East India Company of the Indian defense mechanism.

${ }^{121}$ Nanda, European Travels Accounts during the reign of Shahjahan and Aurangzeb, p. 90.

${ }^{122}$ Stanley J. Tambiah, "What did Bernier actually say? Profiling the Mughal empire," in Veena Das et al. (eds.), Tradition, Pluralism and Identity:Essay in honour of T.N.Madan. (New Delhi: Sage, 1999), pp. 219-243.

${ }^{123}$ Kate Teltscher, India Inscribed, European and British Writing on India. 1600-1800 (Oxford University Press, 1995), p.17. 